\title{
SOME PROBLEMS IN MAINTAINING SUSTAINABILITY OF INDONESIA'S FORESTS: DESCRIPTIVE STUDY
}

\author{
Cecep Handoko ${ }^{1 *}$
}

Received : 18 January 2013, Accepted : 17 March 2014

\begin{abstract}
Indonesia's forests have economic, social, and environmental benefits. Some national efforts, as well as support from the global community for sustaining forest development in Indonesia have been done. However, some problems were still reported during the implementation of the forest development. Thorough analysis was needed to formulate the root of the problems, and to identify solutions/supports to the current forest development to achieve its sustainability. Descriptive analysis was used in this study. The results indicated that sustainable forest development in Indonesia was still faced with the problems of uncertainty of management, insufficient management capacity, and lack of law enforcement. These conditions were indicated by high conflict of interests as well as lack of support from stakeholders, not enough forest management actions at site-level, and high forest degradation. Aiming at overcoming problems of sustainable forest development and maintaining sustainability of Indonesia's forest, national forest management needs to embrace more space for communication, openness, mutual learning, collaboration in addressing forest conflicts, and determining the future direction of its sustainability goal of management.
\end{abstract}

Keywords: Indonesia, forest, sustainable development

\begin{abstract}
ABSTRAK
Hutan Indonesia memiliki manfaat secara ekonomi, sosial, dan lingkungan. Beberapa upaya nasional, begitu pula dukungan dari komunitas global untuk mempertahankan pembangunan hutan Indonesia telah dilakukan. Namun, beberapa masalah masih mengemuka selama pembangunan hutan tersebut. Analisis menyeluruh diperlukan untuk merumuskan akar dari masalah-masalah tersebut, dan mendapatkan solusi / dukungan bagi pembangunan hutan yang berkelanjutan. Analisis deskriptif digunakan dalam penelitian ini. Hasil penelitian menunjukkan bahwa pembangunan hutan yang berkelanjutan di Indonesia masih dihadapkan pada masalah-masalah berupa ketidakpastiaan pengelolaan, rendahnya kapasitas pengelolaan dan rendahnya penegakan hukum. Kondisi tersebut ditandai oleh tingginya konflik kepentingan serta rendahnya dukungan para pihak, rendahnya tindakan-tindakan pengelolaan di tingkat tapak dan tingginya kerusakan hutan. Untuk mengatasi permasalahan pembangunan hutan, pengelolaan hutan nasional perlu membuka ruang yang lebih luas bagi komunikasi, keterbukaan, pembelajaran dan kolaborasi dalam mengatasi konflik-konflik hutan, serta menentukan arah ke depan terhadap tujuan kelestarian dari pengelolaan hutan yang dilakukannya.
\end{abstract}

Kata kunci : Indonesia, hutan, pembangunan berkelanjutan

\footnotetext{
${ }^{1}$ Research Institute of Non Timber Forest Product Technology Jl. Dharma Bhakti No. 7 Po.Box. 1054, Ds. Langko Kec. Lingsar, Lombok Barat, NTB 83371. West Nusa Tenggara - Indonesia

*Corresponding Author: cecep_h@yahoo.com
} 


\section{INTRODUCTION}

Forest is a national capital, which has tangible benefits in ecological, socio-cultural, and economic values (Law number 41 of 1999 on Forestry). As one of the determinants of life supporting systems, forests play important roles in hydrological functions, protection from flood, and erosion. Despite the important functions of the forests, however, Indonesia's forests have been dramatically degraded, as a result of large-scale forest exploitation (The World Bank, 2006b). Natural disasters, decline in forestry incomes, and declining capital for national development are linked to such degradation. Meanwhile, high greenhouse gas emissions caused by deforestation, forest fires, and degradation of peatland has attracted national and global attention because of its impact on global warming. Some of the major concerns in forest development in Indonesia are: illegal logging, land degradation, forest revenue enhancement, community development, and the revitalization function of the forest management unit (FMU) as well as forestry extension. Moreover, since global warming that leads to climate change has negative impact on the raising risks of hydrological-related disasters, including flood and drought, the government of Indonesia has stressed national involvement in climate change adaptation as well as mitigation.

On the other hand, accommodating the changes in the society as well as the requirements of decentralization in the autonomy era, some changes have been done related to the implementation of forestry policies (Subarudi and Dwiprabowo, 2007). Moreover, several local-community empowerment programs were introduced to overcome social conflicts. The programs included Community Forestry (Ministry of Forestry Regulation Number P.37/Menhut-II/2007), village forest (Ministry of Forestry Regulation Number P.49/MenhutII/2008), and Forestry Partnership (Ministry of Forestry Regulation number: P.39/MenhutII/2013). However, social conflicts were still emerging frequently. Social conflicts have been occurring within governmental bodies, multilevel governmental bodies, and governmental bodies with communities and customary groups. Moreover, the occurrence of claim to forest land highlighted conflict condition which has occurred for years. On the other hand, aiming at overcoming social conflict and improving effectiveness of management,

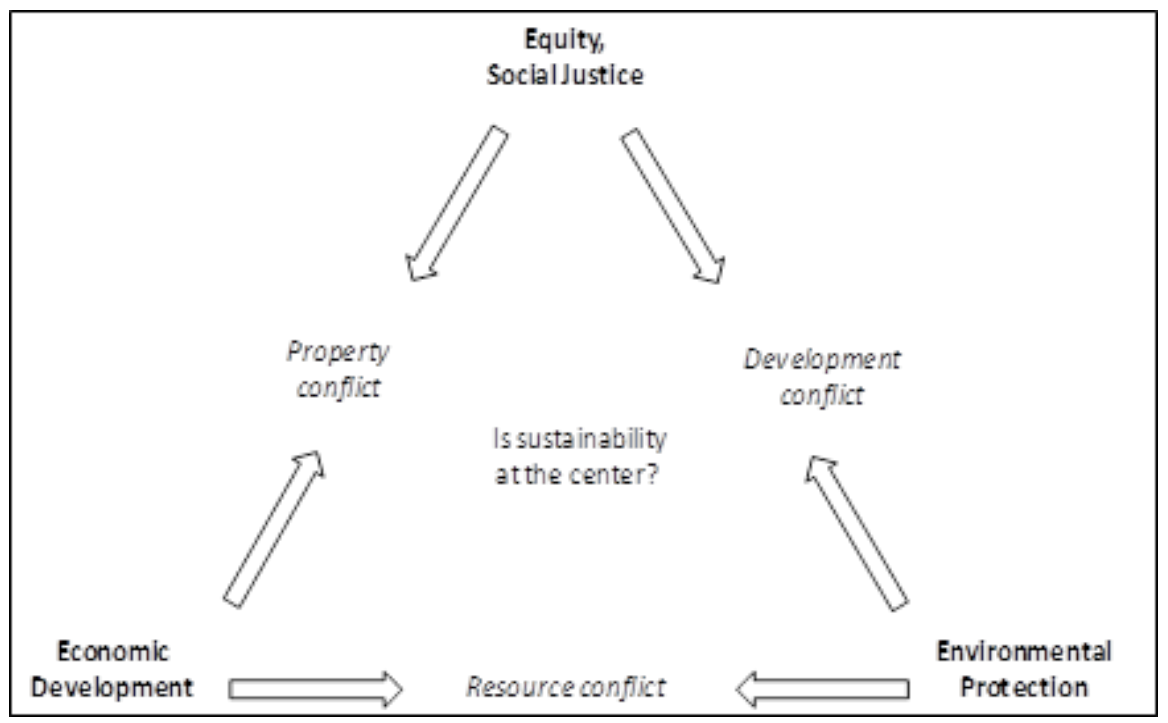

Source: Campbell, 1996

Figure 1. The triangle of conflicting goals for planning, and the three associated conflicts 
including handling of forest land degradation, the establishment of FMU was hampered by lack of human resources and insufficient support from stakeholders (MoF, 2010).

Along with the efforts on sustaining forest development in Indonesia, many contrary reports of problems in forest development were produced. The reports could lead to the question on how Indonesia could achieve sustainability in its forests. Since a solution to forest sustainability in Indonesia should be obtained, a guidance to formulate sustainable forest development strategy as well as to know the root of the problems of development was needed. Campbell (1996) asserted that sustainable development should take into account three conflicting goals of development as well as their three associated conflicts. Sustainable development goals, including economy, social justice/equity, and environmental protection, while the three associated conflicts, include property conflict (economy-equity conflict), resource conflict (economy-environmental conflict), and development conflict (equity-environmental conflict). Sustainable development itself is ideally placed in the center of the triangle of those goals and conflicts (As it can be seen in Figure 1).

In practical term, the triangular model of planning can be used to operationalize longterm vision of sustainable development into a medium-term and short-term planning (Nur, 2010). Using this triangular model of planning, the goals as well as the associated conflicts of the development can be definitely determined, therefore the roots of the problems of sustainable development can be thoroughly analyzed. This results in arriving at the solutions to the development. By using the triangular model of planning, this study was aimed at finding the root of some of the problems of sustainable forest development in Indonesia, and proposing solutions as well as support to the current forest development to achieve its sustainability.

\section{MATERIALS AND METHODS}

\section{A. Materials}

This study used secondary data and information which were obtained from various publications, including news, reviews, reports and research publications.

\section{B. Methods}

This study was a desk study. Data were analyzed descriptively. The main data source was the forestry statistical report of Indonesia from the Ministry of Forestry (MoF). Some other supporting information was also used, including: 1. Some current forestry issues and case studies related to the subject; 2 . The history of the development of the national forest to get an overall picture of the trends in forest development and the problems that are associated with it, and 3. The various stated solutions to the current problems of forestry development.

Steps of analysis included:

1. Collecting data and information to find out mainstream concerns or problems of forest development related to the objectives of forest development;

2. Grouping some mainstream concerns/ problems by their sources of conflicts;

3. Overlaying divergent of interests of forest development (economy, social, and protection of environment) with the associated sources of conflicts (properties conflict, resources conflicts, and development conflicts) to obtain the roots of the forest development problems;

4. Finding possible solution or support in maintaining sustainability of forest development in Indonesia.

\section{RESULTS AND DISCUSSION}

\section{A. Results}

Until 2009, strategic efforts have been made for the successful development of the forests in Indonesia. Some of the efforts, including: (1) completion of 578 cases of illegal logging $(18.75 \%$ of the total of 3,083 


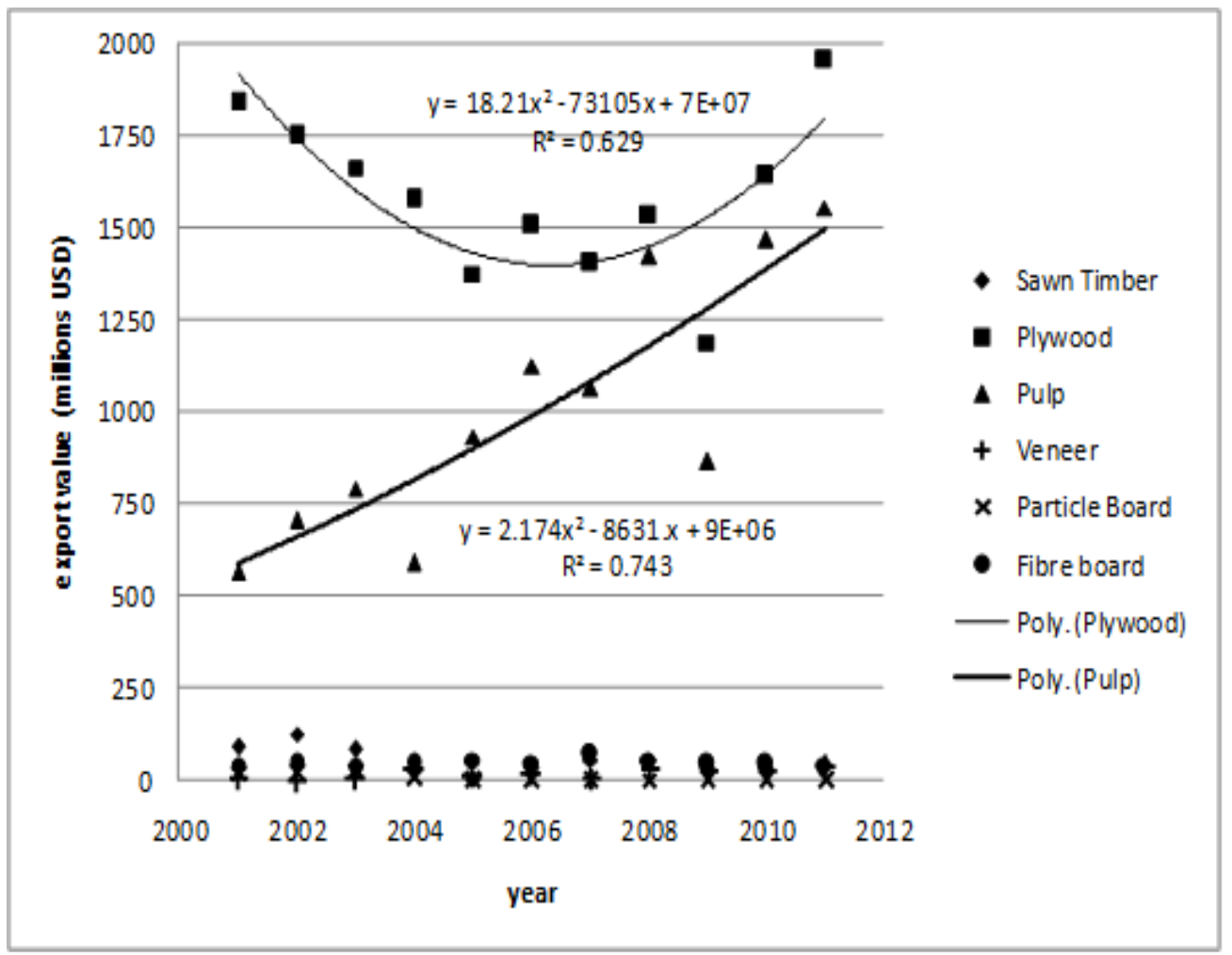

Source: MoF (2006), MoF (2008) and MoF (2012) (data processed)

Figure 2. Export values of processed timber during 2001 - 2011

cases) during 2005-2009; (2) rehabilitation of 906,969 hectares of forest area, and 1,102,912 hectares outside of forest area; (3) development of intensive silviculture system and industrial plantation forests (HTI) reaching a total investment of IDR 23.72 trillion; (4) construction of 227 units of wood processing industries capable of employing 205,300 people reaching a total investment of IDR 16.56 trillion; (5) development of 8,800 hectares of community forests ( $\mathrm{HKm}), 22,860$ hectares of private forests (HR), and 2,360 hectares of village forests; (6) distribution of investment funds to communities for establishment of HTI and private plantation forests (HTR) reaching an investment volume of IDR 4 trillion in 2008; (7) demarcation of $219,606 \mathrm{~km}$ forest boundaries $(77.91 \%$ of the total length of $282,873 \mathrm{~km}$ ); (8) establishment of forest management units (KPH); and (9) institutional and capacity strengthening of the forestry extension (Forestry Minister Regulation Number: P.08/Menhut-II/2010 on Forestry
Ministry's Strategic Plan 2010-2014).

As it is known from the above efforts, illegal logging, land degradation, forest benefit enhancement, community development, and revitalization of the forest management unit as well as forestry extension were some of the major concerns of forest development in Indonesia until 2009. The concerns continued in the next development periode (2010-2014). Meanwhile, as important input for evaluating and obtaining suitable solutions to the current and the future development of the forests in Indonesia, some national or global problems/ issues were reported, as follows:

1. Problems in forest border demarcation and forest area determination

Law number 17 of 2007 on National Long Term Development Plan for 2005 to 2025 stated that the lack of sustainable management of natural resources is still a major obstacle for resolving national spatial planning. Incomplete spatial planning has led to the development of the sector, which does not take into account 
sustainability and environmental capacity, and does not pay attention to the vulnerability to natural disasters. It also has led to conflicts between land use sectors, where the most common example is the conflict between forestry and mining sectors. The completion of national spatial planning, one of the ways is through forest area demarcation, is necessary to accelerate the sustainable management of natural resources in Indonesia.

The fundamental of forest management is forest planning, by which permanent forests have been established. Permanent forest is characterized by the status and the boundaries that is clear, definite, legitimate and recognized by the public and stakeholders, and is accountable. Establishment of permanent forest prevents conflicts and increases security of existing forest, investment assets, biodiversity, and environment. Ministry of Forestry published the size of the terrestrial forest as 131 million hectares out of a total of 136 million hectares which include forests and waters as its forest territorial area. However, until 2011, only 15.22 million hectares or 11.6 percent of the forest area has been gazetted. Beside technical aspects of implementation, slow performance of forest boundary demarcation was influenced by conflicting interests of development of stakeholders, and lack of accommodation of community rights as well as access to forest during boundary demarcation (KPK, 2012).

On the other hand, Forestry Law number 41 of 1999 states that the adequacy of the forest area and forest cover for each watershed and/ or island shall be at minimum 30 percent of the total area of the watershed and/or island which should be proportionally distributed. Although it is a progress from the previous forest policy (Law number 5 of 1967 on Basic Provisions of Forestry), there is no definite inventory to arrive at the absolute numbers of forest area adequacy according to watershed and/or island, besides the inherited history of the forest area of Indonesia from the Dutch administration. Besides the calculation of the initial forest area, there is the calculation of the forest area which is allowed for conversion to the tune of $2 \%$ of the total national forest area (Joint decision by the Minister of Forestry, Minister of Agriculture, and the Head of the National Land Agency number: 364/Kpts-II/90; 519/ Kpts/HK.050/90; and 23 - VIII - 1990), and the calculation of the proportional areas of the non-forest plantations with agricultural plantations by provincial areas (the Minister of Forestry regulation number: P. 33/MenhutII/2010). However, harmonization of the three calculations of the forest areas during the implementation phase, as well as overcoming conflicts, was not done. This condition could lead to divergence forest area allocation for certain mainstreamed purpose of benefits. The accommodation to recent conditions, especially national social changes, could bring on policy changes. But, in fact, it should be worrying that large forest conversions, i.e. conversion to oil palm plantations and conversion for mining, have no definite arrangements, which will lead to natural forest destruction and biodiversity losses in the Indonesian rain forest ecosystems. These conditions were found during 1990-1999 (Manurung, 2001).

On the other hand, disputing the determination of forest area units together with unfinished implementation of forest boundary demarcation is also known. Along with the history of forest management, various concession management units between 1,000 to 400,000 hectares have been issued with licenses. The area of the unit depends on the existing forest area; the forest origin, forest status, and the capacity of management. During the historical period, there was a change in forest management from broad-scale natural forest management to plantation forest management. There was also the establishment of small forest management units of up to 100 hectares (Minister of Forestry Decree number: 05.1/ Kpps/II/2000). Establishment of these small scale forest area units without assurances on management as well as forest boundaries could lead to wide occurrence of small, degraded, and fragmented forest areas. 


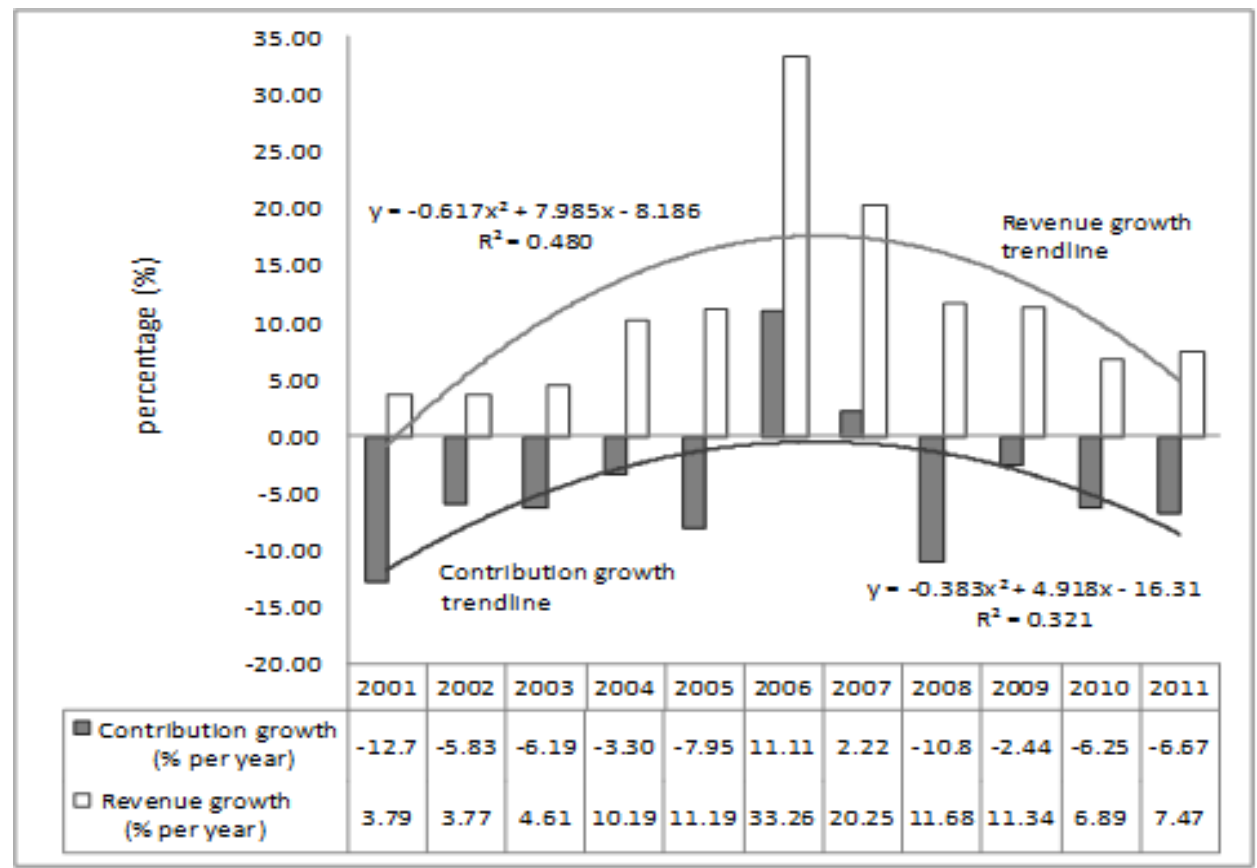

Source: MoF (2006), MoF (2008) and MoF (2012) (data processed)

Figure 3. Trend of Forestry Sector GDP and Contribution of the sector to national GDP

2. Problems in gaining forest revenues and high forest degradation

Since timber exploitation from natural production forests have resulted in excessive forest degradation, the log export ban was issued in 1985. During 1985-1997, the log export ban policy has led to the decline of timber product export revenues by 12 per cent, or a total decrease of USD 6 billion. In contrast, the resumption of $\log$ exports in 1998 has led to the widespread circulation of illegal timber and lack of timber raw material to the industries in the country compelling the Forestry Department (now the Ministry of Forestry) to withdraw the policy in 2001 (Manurung, 2008). Nevertheless, these policies encouraged the growth of domestic wood processing industries such as pulp and plywood industries. As it can be seen in Attachment - Figure 2, pulp exports showed an increasing trend during 2001 to 2011 with cumulative value of foreign exchange of USD 11 billion, while plywood exports also increased during 2006 to 2011.

Figure 2 shows the value of exports of processed timber during the period 2001-2011. Of the eight forest products, the exports value of pulp increased from USD 564 million in 2001 to USD 1,554 millon in 2011. It appears from the figure that the trend of increase in export value of pulp is confirmed signignificantly by the $\mathrm{R} 2$ value, 0.743 , of the regression equation. Meanwhile, plywood exports also increased from 2001 to 2010. Compared to the trend of export values of pulp, trend of plywood export values seem to had its ups and downs characterized by a curved regression line. R2 0.629 of the regression indicates that the regression line is well fitted to the trend of the export value of plywood. On the other hand, it also can be seen that export values of some other products were very low compared to the value of the exports of pulp and plywood.

Figure 3 - in Attachment, shows the trend and the contribution of the forestry sector to the national GDP during 2001-2011. From the figure it can be seen that the $\mathrm{R} 2$ values of the two regressions are only 0.321 and 0.480 , i.e. quite low, which is thought to occur because of the high fluctuation (standard deviation) of values of the independent variables for the contribution of the forestry sector and the national GDP, i.e. 6, 23 and 8.29, respectively. But, in general it can be seen that the growth curve of the national GDP is above zero, while that for the contribution of the forestry sector is below zero. Therefore, from the graph it can 
be seen that the overall contribution of the forestry sector to the growth of the national GDP during the years 2001-2011 was negative. During the period 2001 to 2011, there was a positive growth in GDP of the forestry sector by an average of $11.31 \%$ per year. However, the increasing growth of GDP was not followed by positive growing trend of the sector to the national GDP that declined by an average of $-4.44 \%$ per year over the same period (Figure 3 ). Although using the GDP as the sole measure of the strength or weakness of the sector's role in the national development is debatable, since one is only calculating the tangible product value (Nurrochmat, 2008), but the declining contribution of the forestry sector triggered the need to increase as well as sustain the GDP of the sector.

Besides the low GDP contribution, forest economic development faced problems of massive forest losses and forest degradation. The World Bank (2006b) stated that a quarter of the "state forest area" lacks tree cover and up to 2 million hectares of forest was lost per year. In contrast, forest and land rehabilitation efforts faced obstacles from a low reforestation fund obtained from the economic utilization of the forest. By 2007, critical forest areas have reached 59.2 million hectares and the cost for forest and land rehabilitation (RHL) was estimated at IDR 296 trillion. With assuming a cost of IDR 5 million per hectare, RHL costs cannot be covered by the available amount of the reforestation fund, remaining is approximately IDR 10 trillion, with an addition of IDR 1-2 trillion (Subarudi and Dwiprabowo, 2007). In line with the lack of the reforestation fund, the results of the examination of the financial management of the forestry sector is showing the ineffectiveness of the management with potential irregularities which has caused total state losses of IDR 2.14 trillion (BPK, 2012), that increased the concern about the failure of the Ministry to eradicate nationwide the high rate of forest degradation.

On the other hand, many factors, including external and internal factors considered as the contributing causes to the large forest losses and degradation of Indonesian forests complicated and confused the efforts for overcoming such high forest degradation as well as destruction. Wardojo and Masripatin (2002) stated that large discrepancy between supply and demand of $\log$ production and consumption, which has brought about illegal logging and illegal trade, is the main factor causing large forest degradation. The World Bank (2006b) stated that forest degradation and forest loss in Indonesia was resulted mainly by illegal cutting and land conversion fuelled with excessive processing capacity of industries and lack of effective management and law enforcement. Kartodihardjo (2006a) stated that the forestry programs which were implemented by district/ province governments and central government with lack of institutional strengthening efforts has resulted in policy failures to reach its targets and led to enormous forest destruction. On the other hand, in more general term, Barr et al. (2011) stated that lack of efficiency and accountability has led to insecurity of management as well as forest sustainability.

\section{Social conflicts}

Nurjaya (2005) stated that social conflict in forestry happened due to the state-based government's policies, centralized pattern, which was solely oriented toward economic growth. In line with this, Sumardjani (2005) explained that the rise of the social conflicts in forestry implicitly lies in the history of the forest development during four important periods of time, as follows:

1. 1970-1980. This period has begun with the establishment of timber concessions and timber enterprises in and outside Java. Natural forest timber has been exploited massively, and Indonesia became the largest producer of tropical timber in the world. No social conflict was found during this period. People felt quite satisfied with their lives, even so their social lives can be said to have been simple.

2. Early to mid-1980s. In this period, rush for timber exploitation by concessionaires grown rapidly, up to 454 units of concessions were awarded. It has led to concern about promotion of forest conservation, as well as growth of wood processing industries 
and log export ban was introduced. In 1985, the ban has led the international logging companies to leave Indonesia. Meanwhile, the management of the degraded forests as well as the unproductive wastelands was done by issuing industrial plantation forest management rights (HPHTI). In contrast, the change in forestry development to utilize degraded forest was followed by people's awareness of the gap between their lives compared with the "outside" communities, which were getting higher economic benefits from "their" forests.

3. 1990s. During this period, as the awareness of the communities of the gap increased, the government's concern about forest communities was increasing. The government issued licenses to the holder of forest management rights $(\mathrm{HPH})$ as well as HPHTI to train people in and around the forests. The number of $\mathrm{HPH}$ licenses has grown to 564 units with a total area of 59.62 million hectares, while the forest was divided into three functions, namely protected areas, forestry cultivation region and non-forestry cultivation region. As forest development was continued, HTItrans was created and forest conversion was started. On the other hand, people began to realize that the gap widened.

4. 1998s. This period was marked by Soeharto's resignation due to massive demonstrations of students and the communities and also because of the riots which were destroying public facilities. Economic condition was getting hard due to the economic crisis, and the gap between the realities of living with a reference group could no longer be bearable. In this period, forest dependent people started the massive forest encroachment to feed their families.

The history indicated that gap of economic as well as social welfare between local community and the forest concession management unit has slowly increased community's demand for better economic and social life. However, the increasing demand has been followed by a sense of injustice, the feeling of being neglected, and the disgust that timber concessionaires as well as management has destroyed "their" ancestors' inheritances. After the New Order collapsed in 1998, decentralized development as well as the introduction of autonomy has produced the competition of capital for development between central and district governments (Subarudi and Dwiprabowo, 2007). The social conflict has been raising with some district/ local governments to act as "leaders" to face the central government. On the other hand, social demand has developed from subsistence demand for forest-related social services into demand for forest economic benefits, and the latest demand was for forest land use and ownership. The latest demand resulted in high forest tenure conflicts in most parts of forest areas. The occurrence of forest tenure conflict was resulted from: (1) insufficient or unfair accommodation of forest tenure rights; (2) insufficient capacity of tenure holders to exercise their rights, manage forest sustainably, and develop livelihoods; and (3) inadequate ability of state institutions to support tenure holders and uphold regulations (Mayers et al., 2013). Thus, the social conflicts have been the most hard and complicated problems in sustaining site-level forest management.

4. Global community support related to climate change and global warming issues

Indonesia's consciousness of threatened geographical conditions due to climate change, the commitment of Indonesia to follow the agreement of the Bali Action Plan at the Conferences of Parties (COP 13) to the United Nations Framework Convention on Climate Change (UNFCCC) and the results of COP15 in Copenhagen, and the COP-16 Cancun stressed the commitment of the Government of Indonesia to reduce greenhouse gas emissions by $26 \%$ if done alone and by $41 \%$ with international aid in 2020. The commitment will be integrated in the national development programs, such as stipulated in Presidential Regulation of the Republic of Indonesia Number 61 of 2011 on the National Action 
Plan for Greenhouse Gas Emissions Reduction and Presidential Regulation of the Republic of Indonesia number 71 of 2011 on Greenhouse Gas Inventory Implementation.

Particularly with high greenhouse gas emissions from deforestation, forest fires and peatland degradation, forestry sector is expected to play an important role to reduce greenhouse gas emissions which are mainly located in the territory of forest management. Moediarta and Stalker, 2007, stated that Indonesia should also be able to rely on international assistance - not only for mitigation but also for actions that will be needed to help the poorest people to face the consequences of various weather conditions, which will be increasingly erratic and more extreme. And for that, the global concern for sustainability of forests in Indonesia was important, it needed to support Indonesia's forest development efforts in overcoming high forest degradation as well as the destructive conditions.

In line with the global concern for global warming, the World Bank policy supports Indonesia's forest management on three broad goals including promoting economic growth, providing widespread and equitable benefits to society (livelihoods and poverty reduction), and sustaining environmental services and benefits. Since Indonesia did not achieve all of these goals, the World Bank advised Indonesia's forestry management in engaging the support for:

1. Base level engagement, which calls for scaling up and mainstreaming successful initiatives and approaches, including: forest law enforcement and governance (FLEG), transparency, industrial restructuring and acceleration of plantations, communitydriven development (CDD) of pilot projects, and conservation initiatives.

2. Medium level engagement, with deeper and more focused analytical work, including: forest monitoring and interagency collaboration on law enforcement, better balance between supply and demand for restructuring of industries, promote community-based timber growing efforts by improving the enabling conditions, transparency and revitalization of forest industries. Additionally, this stage would be pursued on land use, resource access and rights issues, proven scale up approaches in CDD and conservation resulting from existing activities.

3. High level engagement, which builds on prior efforts and potentially include lending operations that will help to resolve prior issues, including: forest monitoring, training and technology for law enforcement and information systems, plantation development or small- and medium enterprise promotion, rural livelihood development, and considerable progress on issues of tenure and interest in forest land use rationalization.

Since Indonesian forest development was hampered by hard and complicated problems of economic, environmental, and social conflicts, while increasing attention of global community responding to global warming as well as climate change issues has led to reinforcement of efforts of the Government of Indonesia to overcome high forest degradation as well as destruction, strengthen law enforcement and good governance, and improve community welfare as well as forest conservation, it was hoped that such conditions could lead to the accomplishment of the handling of the forest development problems in Indonesia. Although the hope has not yet being realized, but the efforts continue until today.

\section{B. Discussion}

Forest development in Indonesia will be achieved through five goals, namely ensuring that forests sufficient in area and evenly distributed; achieving a balance and sustainable benefit of forest; improving the carrying capacity of watershed; improving the capacity to develop ability of society; and ensuring equal and sustainable distribution of benefits (Law number 41 of 1999 on Forestry). Basically, the forest development goals are in line with the 


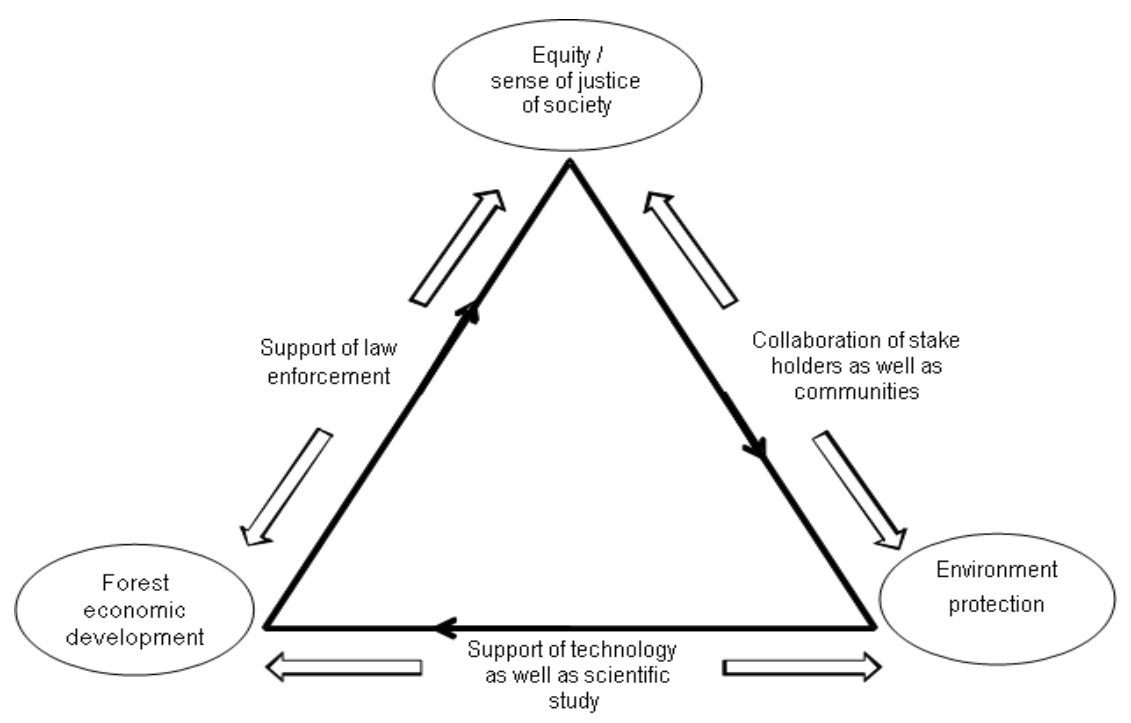

Figure 4. Sustainable forest development framework and supports

three goals of sustainable development, as it was assumed, including economic development, environmental protection, and equity/sense of justice of society (Campbell, 1996). However, the goals were accompanied by the occurrence of related conflicts, including: conflict of claim and use of forest properties, conflict of development, and conflict over forest resources.

Forest property conflict was resulted from collision of goals for economy and equity. Property conflict defines the boundary between private interests and public goods. Since private and customary forest was not included in this type of conflict, it was considered as a good of the state and ruled by the state, the conflict of property as it was stated in Campbell (1996) in this discussion was grounded in those activities that illegally claimed or used state-forest property. The activities included illegal logging, illegal hunting, illegal trading, and illegal occupancy of forest land for purposes of economic benefits. Since large forest destruction and high loss of capital for development of forests were caused by such illegal activities, law enforcement was importantly needed.

On the other hand, since illegal use and claim of forest property by community was mainly resulted from a sense of injustice during the implementation of the state-based forest management, the applicable law enforcement might not touched the root of the problems, but worsened the conflict conditions and led to violent as well as massive community resistance. Moreover, since credible penalties, effective law enforcement, and fair and just legal system in Indonesia were questionable (The World Bank, 2006a), efforts of better communication, extension, and community empowerment should be prioritized more than law enforcement. Meanwhile, building wide understanding, implementing extension, and facilitating implementation of community empowerment programs, the role of third parties as well as forestry extensions were needed. Since the understanding was achieved, the feeling of injustice was overcome, and a fair gain as well as sharing of the economic benefits of the forests was established, a balanced economic-equity relationship of sustainable development could be established.

As it was stated before, the discussion on conflict of forest property has neither included private forest nor customary forest. This was because the interest of the goverment was not fully known as regards to rule the private as well as the customary forest. Development conflict defines the need to increase social equity and protect the environment simultaneously, 
whether in a steady-state of economy or not. In the case that the rule of government on private and customary forest was based on their environmental functions, and ignored the economic value, and for that the increase of community income was not deemed neccesary, the development conflict was appearing. Meanwhile, in the case that the rule of the government was based on economic interest to obtain national revenue from private as well as customary forest, the conflict which was found in this condition was categorized as conflict of property.

It depended on the source of conflicts; sustainable development of both private and customary forest could be obtained by shifting to the center the balance of the economicequity relationship, in case of poverty conflict, or shifting to the center the balance of equityenvironmental relationship, in case of conflict of development. The same explanation was also valid for the conflict which was found during the forest boundary demarcation since the state objectives behind the boundary as well as in changes of forest area determination was known. The root of the conflict could be found since the demarcation included in the forest area non-forest areas i.e. agriculture, settlement, and plantation land. Many forest tenure conflicts were started by such collisioning conditions.

Included in the conflict of development was the rule of the government on forests that ignored the need of economic development of other sectors. This conflict of development could be identified from collision between the interests of the forestry sector on environmental protection with the interests of various non-forestry sectors, including agriculture, plantations, mining, etc. Lack of equity in forest land allocation, use, and access resulted in development of conflict. This conflict could be occurring between development sectors, central and local government, and central government with local communities or customary groups. This conflict was involving various parties as well as communities. For that, the various needs and interests of parties as well as communities complicated the efforts to overcome such conflict of development.

Since the criteria of sustainability of development is depended on, and determined by various parties point of views, solution to sustainable development is resulted from how far various parties have authorities and fair roles in the development (Ngakan et al., 2008), and how fairly natural resources were allocated and distributed among parties as well as resourceuser groups (Wondolleck, 1988). In these considerations, a way for obtaining conflict of development resolution could be achieved by involving various parties in the process of conflict resolution, while collaboration among parties could result in a broader vision of solution, by which conflict resolution could be achieved thoroughly.

On the other hand, contrary aims of obtaining high forest economic benefits that harm the existence of the forest resulted in forest resource conflict. Resource conflict did not define a fixed boundary as it was in property conflict. A boundary was a contradiction between mutually dependent forces, economic and environment, as well as present and future demand. Forest resources conflict in Indonesia was indicated by large loss of forest areas as well as biodiversity, forest degradation and forest fragmentation. Regrettably, such condition was followed by low economic revenue and loss of revenue due to irregularities. Hampered by such contradictive conditions, forestry development should consider to optimize economic benefits as well as to improve productivity of mostly small and fragmented forest areas, increase forest investment, improve management capacity, and overcome irregularities.

In such low economic revenue and high forest degradation of forest development, establishment of industrial plantation forest (HTI) could be another consideration in sustaining forest development. The plantation forest was established on degraded and unproductive forest land. The establishment of HTI could increase productivity and economic value of land and forests, increase employment, 
and enhance the incomes of forest community. Supporting the HTI establishment, a good financing system and good management (Hakim, 2009), an appropriate silvicultural technology and stable market (Cossalter and Pirard, 2006; Wahyudi, 2008), land conflict as well as handling of social conflict (Wahyudi, 2008), and cooperation between community and company in high conflict condition (Martin, 2008) were needed. Meanwhile, in terms of role of the policy in supporting HTI building, Kartodihardjo (2006b) emphasized the needs, including: subsidies/financing system, policy partnerships, and the land use conflict resolution policy.

Related to the need for overcoming problems of forest development in Indonesia, national efforts have been done. The effort was also involving the support from global community which was triggered by the high environmental risks of climate change as well as global warming. In line with this effort, some suggestions for maintaining the sustainability of Indonesia's forest were identified in this study, including: 1. support of law enforcement prioritizing communication, extension, and community empowerment for overcoming illegal access, use and claim to forest land and resources; 2. support of technology/scientific study mainly for improving forest economic revenue, forest productivity, and forest rehabilitation; 3. collaboration of stakeholders as well as communities in overcoming collision or interests of development. The three supports, as it was modified from Campbell (1996), is described in the Attachment - Figure 4.

In line with the supports which were achieved as described in Figure 4, it should be considered by management or society that, originally, natural resources are limited, while the population continues to increase faster than natural resources can recover from disturbances. Since it has happened, Hardin (1968) stated the necessity of restrictions, which are consciously done by society and management, and by applicable laws. On the other hand, since there is a lack of social justice as found in Indonesia and profound social change to overcome conflicts, which will come about putting pressure to vulnerable society, so that presenting ethical guidelines and promoting the importance of third parties are needed to build peace and overcome conflicts (Garcia, 2006). Meanwhile, since social conflict resulted in destruction of local culture and harmed social integrity, the important roles of third parties are to mitigate the hope of the community to accept the reality that is lower than their expectation (Sumardjani, 2005).

Related to statements above, aiming at overcoming social conflict resolution, Dharmawan (2007) stressed the important role of participatory processes and buttomup development approaches. In line with this approach, Olsson et al. ( 2004) stated that a self-organized bottom-up process of adaptive collaborative management (ACM) can improve the success of conflict resolution during the implementation of natural resources management. This adaptive collaborative management includes the following: vision, leadership, and trust; sequence response to environmental events; institutional arrangements; funds; individual/management expands to others; social networks; obtaining and sharing ecological information and knowledge; community-based sense making; and arena of collaborative learning.

\section{CONCLUSION}

1. Sustainable forest development in Indonesia is still faced with problems of uncertainty of management, insufficient management capacity, and lack of law enforcement. These conditions were indicated by high conflict of interests as well as lack of support from stakeholders, weak forest management actions at site-level, and high forest degradation.

2. National forest management needs to adopt more space for communication, openness, mutual learning, collaboration in addressing forest conflicts, and determining 
the future direction of its sustainability goal of management.

\section{REFERENCES}

Badan Pemeriksa Keuangan Republik Indonesia. (2012). Ikbtisar Hasil Pemeriksaan Semester II tabun 2011. Jakarta.

Barr, C., Dermawan, A., Purnomo, H., \& Komarudin, H. (2011). Tata Kelola Kenangan dan Dana Reboisasi Selama Periode Soeharto dan Pasca Soebarto, 1989 - 2009: Suatu Analisis Ekonomi Politik tentang Pembelajaran untuk REDD+. Bogor: +. Center for International Forestry Research (CIFOR).

Campbell, S. (1996). Green Cities, growing cities, just cities? Urban planning and the contradictions of sustainable development. Journal of the American Planning Association, 62(3), 296-312.

Dharmawan, A. H. (2007). Konflik-Sosial and Resolusi Konflik: Analisis Sosio-Budaya (dengan Fokus Perhatian Kalimantan Barat). In Seminar dan Lokakarya Nasional Pengembangan Perkebunan Wilayab Perbatasan Kalimantan, dengan tema:"Pembangunan Sabuk Perkebunan Wilayah Perbatasan Guna Pengembangan Ekonomi Wilayah dan Pertahanan Nasional", Pontianak. 10-11 Januari 2007.

Garcia, E. (2006). Addressing Social Change in Situations of Violent Conflict: A Practitioner's Perspective. In D. Bloomfield, M. Fischer, \& B. Schmelzle (Eds.), Social Change and Conflict Transformation (Bergbof Handbook for Conflict Transformation Dialogue Series Issue No. 5) (pp. 39-48). Berlin: Berghof Research Center for Constructive Conflict Management.

Hakim, I. (2009). Kajian Pembiayaan Pembangunan Hutan Tanaman Industri. Jurnal Penelitian Sosial Dan Ekonomi Kehutanan, 6(2), 135-158.

Hardin, G. (1968). The Tragedy of the Commons. Science, 162(1243-1248). Retrieved from www. sciencemag.org

Kartodihardjo, H. (2006). Masalah Kapasitas Kelembagaan dan Arah Kebijakan Kehutanan: Studi Tiga Kasus. Jurnal Manajemen Hutan Tropika, 12(3), 14-25.

Kartodihardjo, H. (2006). Masalah Kelembagaan dan Kebijakan Pengembangan Hutan Tanaman Industri di Indonesia. In Tantangan dalam Mewrijud-nyatakan Pembangunan Hutan Tanaman Industri di Indonesia, Jakarta 11 September 2006.

Komisi Pemberantasan Korupsi. (2012). Integrated White Paper Semiloka Menuju Kawasan Hutan yang Berkepastian Hukum dan Berkeadilan. Jakarta.
Manurung, E. G. (2001). Analisis Valuasi Ekonomi Investasi Perkebunan Kelapa Sawit di Indonesia. Jakarta: Environmental Policy and Institutional Strengthening (EPIQ).

Manurung, E. G. T. (2008). Dampak Larangan Ekspor Kayu Bulat terhadap Sektor Kehutanan Indonesia. Retrieved October 01, 2012, from www.fwi.or.id

Martin, E. (2008). Evaluasi Kinerja Ekonomi Hutan Tanaman Industri Pulp Pola Kemitraan. Info Sosial Ekonomi, 8(2), 87-98.

Mayers, J., Morrison, E., Rolington, L., Studd, K., \& Turrall, S. (2013). Improving governance of forest tenure: apracticalguide (Governance of Tenure Technical Guide No.2). London and Roma: International Institute for Environment and Development, and Food and Agriculture Organization of the United Nations.

Ministry of Forestry. (2012). Forestry Statistics of Indonesia 2011. Jakarta.

Ministry of Forestry. (2006). Forestry Statistics of Indonesia 2005. Jakarta.

Ministry of Forestry. (2008). Forestry Statistics of Indonesia 2007. Jakarta.

Ministry of Forestry. (2010). Pembangunan Kesatuan Pengelolaan Hutan (KPH): Konsep, Peraturan Perundangan dan Implementasi. Jakarta: Ministry of Forestry - Deutsche Gesellschaft fur Internationale Zusammenarbeit (GIZ) - Forest and Climate Change Programme (FORCLIME). Forest Planning Agency.

Moediarta, R., \& Stalker, S. (2007). Sisi lain perubahan iklim: Mengapa Indonesia harus beradaptasi untuk. melindungi rakyat Miskinnya. Jakarta: UNDP.

Mur, H. (2010). Model Pemetaan Konflik dalam Perencanaan Pembangunan Berkelanjutan. Tingkap, 6(2), 25-34.

Ngakan, P. O., Komarudin, H., \& Moeliono, M. (2008). Menerawang Kesatuan Pengelolaan Hutan di Era Otonomi Daerah (Governance Brief). Bogor: Center for International Forestry Research (CIFOR).

Nurjaya, I. N. (2005). Sejarah Hukum Pengelolaan Hutan di Indonesia. Jurisprudence, 2(1), 35-55.

Nurrochmat, D. R. (2008). Kontribusi Kebutanan terhadap Produk Domestik Bruto. Paper presented at the Rakor Mitra Praja Utama Dinas Kehutanan Provinsi Jawa Barat Tahun 2008: "PDRB Hijau dan Bisnis Kehutanan". Hotel Kedaton, Bandung 23 Juli 2008.

Olsson, P., Folke, C., \& Berkes, F. (2004). Adaptive Comanagement for Building Resilience in Social-Ecological Systems. Environmental 
Mangement, 34(1), 75-90.

Pirard, R., \& Cossalter, C. (2006). The Revival of Industrial Forest Plantations in Indonesia's Kalimantan Provinces: Will they help eliminate fiber shortfalls at Sumatran pulp mills or feed the China market? (Working Paper No.37). Bogor: Center for International Forestry Research (CIFOR).

Subarudi, \& Dwiprabowo, H. (2007). Otonomi Daerah Bidang Kebutanan: Implementasi dan Tantangan Kebijakan Perimbangan Keuangan. Bogor: Center for International Forestry Research (CIFOR).

Sumardjani, L. (2005). Konflik Sosial Kehutanan: Mencari Pemahaman untuk Penyelesaian Terbaik. Retrieved September 27, 2012, from www.konflik.rimbawan.com

The World Bank. (2006a). Strengthening Forest Law Enforcement and Governance Addressing a Systemic Constraint to Sustainable Development. Washington, D.C.

The World Bank. (2006b). Sustaining Indonesia's Forest: Strategy for the World Bank 2006-2009. Washington, D.C.

Wahyudi. (2008). Evaluasi Pembangunan Hutan Tanaman Industri Kelas Perusahaan Kayu Sengon di IUPHHK-HT PT Gunung Meranti Provinsi Kalimantan Selatan. In Lokakarya Nasional Penerapan Multisistem Silvikultur pada Pengusahaan Hutan Produksi, Bogor 22 Agustus 2008.

Wardojo, W., \& Masripatin, N. (2002). Trends in Indonesian Forestry Policy. Policy Trend Report, 77-78.

Wondolleck, J. M. (1988). Public Lands Conflict and Resolution: Managing National Forest Disputes. New York: Springer Science+Business Media, LLC. 